\title{
PAJAK PENGHASILAN ORANG PRIBADI USAHA MIKRO DAN KECIL DI INDONESIA: KEBIJAKAN DAN IMPLIKASI
}

\author{
Fany Inasius \\ Accounting Department, Faculty of Economic and Communication, BINUS University \\ Jln. K.H. Syahdan No.9, Palmerah, Jakarta Barat 11480 \\ wyndtheo@binus.ac.id
}

\begin{abstract}
Income Tax, whether it is personal or business entities taxpayers, with circulation up to 4.8billion rupiah is 1 percent and the final since July 1, 2013 according to the Government Regulation number 46 year of 2013 (PP46). This paper analyzes the implications of this regulation for micro and small businesses taxpayer with the category of gross circulation to 600 million rupiah. From the research that is conducted by the method of comparative research, descriptive and document analysis, it is showed that this regulation can reduce the compliance cost due to the simplicity of the calculation. However, the imposition of income tax according to the PP 46 is higher than before this regulation is applied for personal entities taxpayer of micro and small business with a turn over up to 600 million rupiah. On the other hand, for personal entities taxpayer of middle business, with the highest circulation, the imposition of income tax is lower
\end{abstract}

Keywords: micro self-employed taxpayer, small self-employed taxpayer

\begin{abstract}
ABSTRAK
Pajak Penghasilan baik Wajib Pajak Orang Pribadi maupun Wajib Pajak badan usaha dengan peredaran sampai 4.8 milyar rupiah adalah 1 persen dan bersifat final sejak 1 Juli 2013 sesuai Peraturan Pemerintah nomor 46 tahun 2013. Paper ini menganalisa implikasi Peraturan ini bagi Wajib Pajak Orang Pribadi usaha Mikro dan kecil dengan kategori peredaran usaha sampai 600 juta rupiah. Dari penelitian yang dilakukan dengan metode penelitian komparatif, deskriptif dan analisa dokumen didapatkan hasil bahwa peraturan ini dapat mengurangi biaya compliance cost karena kesederhanaan penghitungan. Namun, pengenaan Pajak Penghasilan berdasarkan Peraturan Pemerintah nomor 46 lebih tinggi dibandingkan sebelum berlakunya peraturan ini baik bagi Wajib Pajak Orang Pribadi usaha mikro maupun usaha kecil dengan omzet sampai 600 juta rupiah. Di sisi lain, bagi Wajib Pajak usaha menengah dengan peredaran tertinggi pengenaan PPh menjadi lebih rendah.
\end{abstract}

Kata kunci: wajib pajak orang pribadi usaha mikro, wajib pajak orang pribadi usaha kecil 


\section{PENDAHULUAN}

Peranan Usaha Mikro Kecil dan Menengah (UMKM) sebagai sumber utama pertumbuhan ekonomi di berbagai negara terus memberikan kontribusi yang signifikan. Secara umum, perkembangan UMKM di berbagai negara dimulai dari perusahaan perseorangan yang berkembang menjadi perusahaan dengan skala kecil sampai dengan perusahaan dengan skala besar. Rata-rata kontribusi Usaha Kecil Menengah (UKM) di berbagai Negara, dalam menyediakan kesempatan kerja khususnya di Asia Pasifik mencapai 60 hingga 70 persen (Hall, 2002).

Sebagaimana UKM di berbagai negara yang berkontribusi secara signifikan secara global bagi pertumbuhan ekonomi (ESCAP, 2012), UMKM Indonesia berjumlah sekitar 56 juta UKM yang menampung sekitar 97 persen tenaga kerja pada tahun 2012 dengan kontribusi terhadap PDB sekitar 60 persen (Kementerian Koperasi dan UMKM, 2012). Oleh karena itu, pengembangan sektor ini merupakan bagian yang krusial dalam pertumbuhan ekonomi secara keseluruhan. Namun hal ini tidak mudah karena tantangan dan hambatan yang dibutuhkan untuk memahami dan mengatasi persoalan terkait UMKM. Peraturan Pemerintah, khususnya perpajakan, merupakan salah satu persoalan utama yang dihadapi dunia bisnis di berbagai negara. Pengalaman internasional menunjukkan bahwa biaya regulasi tampaknya tidak terbagi secara proporsional untuk UKM (Sandford et al. 1989).

Dunia bisnis, apapun ukurannya, wajib patuh pada peraturan pajak yang berlaku. Di Indonesia, sejak reformasi Undang-Undang Pajak Penghasilan (UU PPh) tahun 2000 menjadi UU PPh nomor 36 tahun 2008, telah memberikan kontribusi keringanan tarif PPh bagi Wajib Pajak (WP) Badan UKM dengan pengurangan tarif sebesar 50\% dari tarif WP Badan. Walaupun UU PPh nomor 36 tahun 2008 tidak secara explicit mendefinisikan tentang UMKM, namun dapat diketahui bahwa pemberian fasilitas tersebut ditujukan bagi usaha kecil dengan batasan peredaran usaha sebesar 4.8 milyar rupiah. Selanjutnya dengan Peraturan Pemerintah nomor 46 tahun 2013 (PP 46), yang mulai diberlakukan pada tanggal 1 Juli tahun 2013, penghitungan PPh mengalami perubahan bagi Wajib Pajak dengan peredaran usaha (omzet) sampai 4.8 milyar rupiah yaitu pengenaan pajak bersifat final sebesar $1 \%$ dari omzet baik untuk WP badan maupun Orang Pribadi (OP)

Penelitian ini bertujuan untuk menganalisa implikasi penerapan kebijakan Peraturan Pemerintah nomor 46 tahun 2013 terhadap Wajib Pajak Orang Pribadi (WPOP) usaha Mikro dan kecil di Indonesia. Dalam konteks ini, penelitian diharapkan dapat berkontribusi pada pengenaan pajak penghasilan bagi usaha mikro dari perspektif Indonesia. Selain itu, penelitian ini juga diharapkan dapat memberi masukan tentang implikasi penerapan PP 46 bagi PPh WPOP usaha mikro.

Pembahasan ini memfokuskan pada WPOP mikro dan WPOP Kecil dengan peredaran usaha sampai dengan 600 juta rupiah. Penelitian ini dimulai dengan pembahasan peraturan terkini tentang PPh bagi WP UMKM. Pembahasan berikut tentang perbandingan penerapan PP 46 terhadap WPOP usaha Mikro dan Kecil. Selanjutnya, pembahasan tentang implikasi PPh atas usaha Mikro dan Kecil. Adapun bagian terakhir merupakan kesimpulan.

\section{Tinjauan Pustaka}

Definisi Usaha Mikro, Kecil dan Menengah (UMKM) bervarisi antar negara yang satu dengan negara lain. Di Indonesia, UMKM diatur dalam UU nomor 20 tahun 2008 yang mendefinisikan UMKM dalam tiga kriteria yaitu usaha mikro, kecil dan menengah. Sesuai UU Nomor 20 tahun 2008, maka usaha Mikro adalah usaha yang memiliki hasil penjualan tahunan sampai dengan Rp 300.000.000,00 (Tiga Ratus juta rupiah), di mana usaha kecil adalah usaha yang penjualan tahunan antara 300.000.000,00 rupiah sampai 2.500.000.000,00 rupiah (Dua setengah milyar rupiah). Adapun usaha menengah adalah usaha yang memiliki jumlah penjualan (omzet) tahunan antara Rp 2.500.000.000,00 (Dua setengah milyar rupiah) sampai Rp 50.000.000.000,00 (lima puluh milyar rupiah). 
Secara perpajakan, pengertian UMKM tidak diatur secara khusus dalam Undang-Undang Pajak Penghasilan (UU PPh), namun secara implicit dalam penghitungan tarif pasal $31 \mathrm{E} \mathrm{UU} \mathrm{PPh,}$ memberikan fasilitas pengurangan tarif bagi Wajib Pajak (WP) badan, dengan peredaran bruto sampai dengan 4.8 milyar rupiah sebesar $50 \%$ dari tarif yang berlaku. Mengingat jumlah peredaran bruto sampai dengan 4.8 milyar berada pada kategori usaha mikro, kecil dan menengah sesuai UU Nomor 20 tentang UMKM, maka dapat disimpulkan bahwa tarif ini diberikan bagi WP badan dengan kategori UMKM.

Sesuai dengan UU PPh tahun 2008 maka subjek pajak penghasilan dapat berupa badan maupun Orang Pribadi (OP). Adapun tarif atas kedua subjek pajak tersebut diatur dalam pasal 17 UU PPh tahun 2008. Untuk Wajib Pajak Orang Pribadi (WPOP) dibagi menjadi empat lapisan yaitu untuk penghasilan kena pajak sampai dengan 50 juta rupiah dengan tarif 5 persen, penghasilan kena pajak antara 50 juta rupiah sampai 250 juta rupiah dengan tarif 15 persen, penghasilan antara 250 juta sampai 500 juta dengan tarif 25 persen, dan terakhir untuk penghasilan kena pajak di atas 500 juta rupiah dengan tarif 30 persen. Selanjutnya, pada pertengahan tahun 2013, pemerintah mengeluarkan Peraturan Pemerintah nomor 46 tahun 2013 (PP 46) tentang PPh dari usaha yang diperoleh WP yang memiliki peredaran bruto tertentu. Adapun WP yang dikenakan PPh sesuai peraturan ini adalah WPOP dan WP badan dengan omzet tidak melebihi 4.8 milyar dalam satu tahun pajak. Untuk WPOP usaha, tidak termasuk WPOP yang menerima penghasilan jasa sehubungan dengan pekerjaan bebas maupun WPOP pedagang kaki lima. Dengan demikian sesuai PP 46, seluruh WPOP pedagang eceran dengan omzet tidak melebihi 4.8 milyar dikenakan PPh bersifat final sebesar $1 \%$ dari total peredaran usaha (omzet).

Sesuai UU PPh tahun 2008, maka PPh atas WPOP dikenakan atas Penghasilan Kena Pajak, di mana Penghasilan Kena Pajak diperoleh dari Penghasilan bersih dikurangi oleh Penghasilan Tidak Kena Pajak (PTKP). Adapun PTKP sesuai UU PPh tahun 2008 sebagaimana diatur dalam Peraturan Menteri Keuangan Nomor 162/PMK.011/2012 tentang Penyesuaian Besarnya Penghasilan Tidak Kena pajak yang mulai berlaku per 1 Januari tahun 2013 memberi batasan PTKP/tahun untuk WPOP dengan perincian sebagai berikut: (1) Untuk WPOP sendiri sebesar Rp 24.300.000,00 (2) Untuk WPOP kawin tambahan sebesar Rp 2.025.000,00 (3) Untuk isteri yang penghasilannya digabung dengan penghasilan suami Rp 24.300.000,00 (4) Tambahan untuk setiap anggota keluarga sedarah dan semenda dalam garis keturunan lurus serta anak angkat, maksimal tiga orang untuk setiap keluarga, masing-masing $\mathrm{Rp} 2.025 .000,00$

Pengenaan PPh bagi WPOP usaha sebelum berlakunya PP nomor 46 tahun 2013 adalah Penghasilan Kena Pajak dikalikan tarif $\mathrm{PPh}$ sesuai pasal $17 \mathrm{UU} \mathrm{PPh}$ tahun 2008. Adapun Penghasilan.Kena Pajak diperoleh dari laba bersih usaha dikurangi PTKP. Untuk mendapatkan laba bersih bagi WPOP usaha dapat diperoleh dengan menggunakan pembukuan atau norma penghitungan penghasilan neto. Tarif norma sesuai UU PPh diatur dalam Keputusan Direktur Jenderal Pajak Nomor 536/PJ./2000. Disamping itu, bagi WPOPyang melakukan usaha baik secara grosir maupun eceran dan atau penyerahan jasa,pengenaan PPh sebesar $0.75 \%$ dari jumlah peredaran bruto, dimana angsuran tersebut merupakan kredit pajak atas PPh untuk tahun pajak yang bersangkutan, sesuai pasal 25 ayat (7) UU PPh tahun 2008 sebagaimana diatur lebih lanjut dalam Peraturan Menteri Keuangan Nomor 208/PMK.03/2009. Namun pengenaan tarif ini menimbulkan cost of tax compliance bagi WPOP pengusaha tertentu kategori usaha mikro (Inasius, 2013). Selanjutnya, dengan berlakunya PP nomor 46 maka pengenaan PPh adalah sebesar 1\% final dari omzet tanpa memperhitungkan PTKP WPOP usaha, dengan omzet sampai dengan 4.8 milyar rupiah yang mulai berlaku 1 Juli 2013.

Pengenaan PPh berdasarkan PP 46 mempermudah penghitungan pajak penghasilan bagi usaha UMKM yang dapat mengurangi cost of taxation. Pengalaman international secara luas, sering mengindikasikan kesulitan yang dihadapi usaha UMKM dalam mematuhi peraturan yang berlaku khususnya dalam menyajikan laporan pencatatan yang layak untuk tujuan perpajakan dan manajemen (Evans et al., 2005). Selanjutnya, Freedman (2003) membahas faktor yang complicated dalam 
menetapkan dan mendesain ketentuan pajak bagi usaha kecil. Menurut Freedman (2003), adalah lebih penting peraturan pajak yang sederhana daripada bermacam-macam ketentuan khusus yang berpotensi menjadi ketentuan pajak yang complex. Sebagaimana ditegaskan oleh Pope (1993b) bahwa ketentuan pajak yang sederhana akan meminimalkan tax compliance cost. Bahkan,penelitian-penelitian terdahulu menunjukkan bahwa tax compliance cost menjadi beban bagi usaha kecil secara tidak proportional (Sandford et al., 1989).

Sebagaimana UMKM di berbagai negara, UMKM di Indonesia memainkan peranan yang significant bagi perekonomian nasional dengan jumlah usaha mencapai 56 juta unit, menampung sekitar 97 persen tenaga kerja serta menyumbang sekitar 60 persen dari PDB di tahun 2012 (Kementerian Koperasi dan UKM, 2012). Disamping kontribusi UMKM yang dominan bagi perekonomian, secara kontradiktif usaha jenis ini mengalami kendala dalam berkompetisi dengan usaha besar. Oleh karena itu,insentifpajak diperlukan sebagai spillover effect bagi ekonomi yang lebih luas serta mengurangi beban usaha UMKM (ESCAP, 2012).

Pengenaan pajak berdasarkan omzet memiliki beberapa kelemahan antara lain beban pajak yang tinggi bagi perusahaan dengan tingkat peredaran kecil, pajak yang tinggi saat laba perusahaan turun atau rugi, serta memberi beban pajak yang rendah bagi perusahaan yang memiliki tingkat keuntungan tinggi (IFC, 2007). Selain itu, pengenaan PPh berdasarkanperedaran usaha cenderung mendistorsi dan tidak mendorong pertumbuhan UMKM (OECD, 2012).

\section{METODE}

Metode yang digunakan dalam penelitian ini adalah metode penelitian komparatif, deskriptif dan analisa dokumen. Penelitian komparatif dilakukan dengan melakukan penyelidikan dan pemahaman terhadap peraturan perpajakan yang telah berlaku dan dikaitkan dengan reaksi subjek penelitian, dengan pengumpulan data yang berasal dari peraturan perpajakan. Adapun penelitian deskriptif dilakukan dengan menggambarkan serta melakukan penilaian atas peraturan yang telah ada. Berdasarkan analisa literatur dan observasi terhadap data-data yang diperoleh dibuat perbandingan yang dapat memberikan gambaran untuk menjawab pertanyaan mengenai tujuan penelitian.

\section{HASIL DAN PEMBAHASAN}

\section{Perpajakan atas WP UMKM}

Peraturan Pemerintah Nomor 46 tahun 2013 yang mulai berlaku 1 Juli 2013, memberlakukan pengenaan PPh berdasarkan omzet penjualan per bulan tanpa memperhatikan tingkat keuntungan yang diperoleh WP baik itu WPOP usaha maupun WP Badan. Bagi WPOP usaha dengan berlakunya peraturan ini memudahkan pelaksanaan pemenuhan kewajiban perpajakan khususnya dalam menghitung jumlah PPh terhutang. Bila sebelum berlaku PP 46,bagi WPOP usaha, penghitungan PPh dapat dilakukan dengan terlebih dahulu menghitung jumlah Penghasilan Kena pajak. Adapun Penghasilan Kena pajak (Ph.KP) dapat dihitung dengan menggunakan norma atau pembukuan.

Bagi WPOP usaha penghitungan PPh dengan menggunakan norma lebih memudahkan pemenuhan kewajiban perpajakan dibandingkan dengan menggunakan pembukuan, walaupun penggunaan norma dirasakan kurang memberikan rasa keadilan (Sari, 2012). Sebaliknya, bila WPOP usaha menggunakan pembukuan, hal ini berdampak pada timbulnya cost of taxation.Dengan demikian hal ini menjadi sulit bagi WPOP usaha untuk comply pada peraturan pajak yang berlaku. 
Ketidakjujuran WPOP dan cost of taxation memungkinkan WPOP usaha semakin tidak patuh dalam pemenuhan kewajiban pajak yang ada.

PP 46 lebih menyederhanakan penghitungan $\mathrm{PPh}$ bagi WPOP usaha dibandingkan penghitungan $\mathrm{PPh}$ sebelum peraturan ini berlaku. Hal ini disebabkan kesederhanaan yang ada dari peraturan ini, yaitu penghitungan $\mathrm{PPh}$ berdasarkan omzet dengan tarif yang flat sepanjang peredaran usaha WPOP belum melebihi 4.8 milyar rupiah. Dengan demikian, WPOP hanya mendokumentasikan dan menghitung jumlah peredaran usaha untuk dapat menghitung PPh yang harus dibayar, tanpa perlu menghitung kembali kekurangan atau kelebihan bayar PPh di akhir tahun pajak karena sifat pajak yang Final dari peraturan ini. Untuk memperjelas kesederhanaan peraturan ini, berikut diilustrasikan seorang WP memiliki usaha penjualan barang kelontong di sebuah pasar dengan jumlah penjualan selama sebulan sebesar 50 juta rupiah. Maka, untuk pemenuhan kewajiban PPh setiap bulan, WP tersebut tidak wajib membuat perhitungan Rugi-laba yang complicated. PPh yang wajib dibayar oleh WPOP tersebut adalah mengalikan 1\% dari 50 juta rupiah sehingga didapatkan PPh terhutang sebesar 500 ribu yang wajib dibayar pada bulan berikutnya. Dengan demikian dapat dilihat kemudahan dari peraturan ini dibanding sebelum peraturan ini berlaku. Hal ini sejalan dengan yang dibahas oleh Judith Freeman (2003) bahwa peraturan pajak yang sederhana lebih penting bagi usaha kecil dibandingkan ketentuan-ketentuan yang terlalu banyak yang berpotensi menimbulkan tax complexity.

\section{Perbandingan PP 46pada WPOP usaha Mikro dan Kecil}

Sebagaimana dinyatakan dalam PP Nomor 46 tahun 2013 maka dapat disimpulkan bahwa WPOP usaha yang memiliki peredaran bruto sampai dengan 4.8 milyar rupiah dikenakan PPh $1 \%$ dan bersifat final. Adapun usaha yang tidak termasuk kategori dalam peraturan ini adalah usaha pedagang kaki lima dan jasa sehubungan dengan pekerjaan bebas. Dengan demikian WPOP usaha yang dikenakan peraturan ini adalah pedagang eceran orang pribadi yang memiliki tempat usaha tetap.

Selanjutnya, bagi WPOP usaha yang tidak memenuhi kategori PP nomor 46 tidak boleh menggunakan peraturan ini dalam penghitungan pajak terhutang. Namun, bagi WPOP usaha yang tidak boleh menggunakan peraturan ini, mendapat fasilitas PTKP sebagai pengurang Penghasilan yang dikenakan pajak dibandingkan WPOP yang wajib menggunakan tarif sesuai PP nomor 46. Hal ini akan berdampak pada penghitungan pajak penghasilan terhutang dari kedua kelompok WPOP usaha (mikro dan kecil) baik yang dikenakan tarif sesuai PP nomor 46 maupun yang tidak diperkenankan.

Untuk memberikan gambaran tentang PPh atas WPOP Mikro dan Menengah dengan omzet Rp 300 juta sampai Rp 600 juta, berikut diilustrasikan perhitungan PPh WPOP sebelum berlakunya PP nomor 46 dan setelah berlakunya PP tersebut.

Contoh berikut mengilustrasikan usaha perdagangan eceran Orang Pribadi (OP) sebelum berlakunya PP nomor 46 tahun 2013, berstatus tidak kawin tanpa tanggungan (TK/0) hingga Kawin dengan 3 anak (K/3), dengan tingkat peredaran yang berbeda, dimulai dari omzet 300 juta rupiah hingga 600 juta rupiah. Adapun tingkat keuntungan yang digunakan sebagaimana yang dinyatakan Sari (2012) sebesar 10\% hingga 15\%. Selanjutnya, formula untuk penghitungan pajak penghasilan terhutang WPOP adalah sebagai berikut:

Penghasilan kena pajak= Penghasilan bersih- PTKP

Penghasilan bersih $=$ Tingkat keuntungan $\mathrm{X}$ Total Peredaran Usaha

PPh terhutang:

Penghasilan bersih sampai dengan 50 juta rupiah: tarif 5\%

Penghasilan bersih di atas 50 sampai 250 juta rupiah: tarif 15\% 
Berdasarkan perhitungan formula di atas, ditampilkan PPh dengan pertanggungan mulai dari TK/0 (tidak kawin tanpa tanggungan) hingga K/3 (kawin dengan 3 tanggungan), dengan peredaran usaha Rp 300 juta, Rp 400 juta, Rp 500 juta dan Rp 600 juta secara berturut-turut yang dimulai dari tabel 1 hingga tabel 4.

Tabel 1 Peredaran Usaha Rp 300 juta

\begin{tabular}{lcrrrrr}
\hline & Laba 10\% & laba 11\% & Laba 12\% & laba 13\% & laba 14 \% & \multicolumn{1}{c}{ Laba $15 \%$} \\
\hline $\mathrm{PPh}: \mathrm{TK} / 0$ & 285,000 & 435,000 & 585,000 & 735,000 & 885,000 & $1,035,000$ \\
$\mathrm{PPh}: \mathrm{K} / 0$ & 183,750 & 333,750 & 483,750 & 633,750 & 783,750 & 933,750 \\
$\mathrm{PPh}: \mathrm{K} / 1$ & 82,500 & 232,500 & 382,500 & 532,500 & 682,500 & 832,500 \\
$\mathrm{PPh}: \mathrm{K} / 2$ & - & 131,250 & 281,250 & 431,250 & 581,250 & 731,250 \\
$\mathrm{PPh}: \mathrm{K} / 3$ & - & 30,000 & 180,000 & 330,000 & 480,000 & 630,000 \\
\hline
\end{tabular}

Tabel 2 Peredaran Usaha Rp 400 juta

\begin{tabular}{lrrrrrc}
\hline & Laba 10\% & laba 11\% & Laba 12\% & laba 13\% & laba 14\% & \multicolumn{1}{c}{ Laba 15\% } \\
\hline PPh:TK/0 & 785,000 & 985,000 & $1,185,000$ & $1,385,000$ & $1,585,000$ & $1,785,000$ \\
PPh:K/0 & 683,750 & 883,750 & $1,083,750$ & $1,283,750$ & $1,483,750$ & $1,683,750$ \\
PPh:K/1 & 582,500 & 782,500 & 982,500 & $1,182,500$ & $1,382,500$ & $1,582,500$ \\
PPh:K/2 & 481,250 & 681,250 & 881,250 & $1,081,250$ & $1,281,250$ & $1,481,250$ \\
PPh:K/3 & 380,000 & 580,000 & 780,000 & 980,000 & $1,180,000$ & $1,380,000$ \\
\hline
\end{tabular}

Tabel 3 Peredaran Usaha Rp 500 juta

\begin{tabular}{lrccccc}
\hline & Laba $10 \%$ & laba $11 \%$ & Laba $12 \%$ & laba $13 \%$ & laba $14 \%$ & Laba $15 \%$ \\
\hline $\mathrm{PPh}: \mathrm{TK} / 0$ & $1,285,000$ & $1,535,000$ & $1,785,000$ & $2,035,000$ & $2,285,000$ & $2,605,000$ \\
$\mathrm{PPh}: \mathrm{K} / 0$ & $1,183,750$ & $1,433,750$ & $1,683,750$ & $1,933,750$ & $2,183,750$ & $2,301,250$ \\
$\mathrm{PPh}: \mathrm{K} / 1$ & $1,082,500$ & $1,332,500$ & $1,582,500$ & $1,832,500$ & $2,082,500$ & $1,997,500$ \\
$\mathrm{PPh}: \mathrm{K} / 2$ & 981,250 & $1,231,250$ & $1,481,250$ & $1,731,250$ & $1,981,250$ & $1,693,750$ \\
$\mathrm{PPh}: \mathrm{K} / 3$ & 880,000 & $1,130,000$ & $1,380,000$ & $1,630,000$ & $1,880,000$ & $2,130,000$ \\
\hline
\end{tabular}

Tabel 4 Peredaran Usaha Rp 600 juta

\begin{tabular}{lcccccc}
\hline & Laba 10\% & laba 11\% & Laba 12\% & laba 13\% & laba 14 \% & Laba $15 \%$ \\
\hline $\mathrm{PPh}: \mathrm{TK} / 0$ & $1,785,000$ & $2,085,000$ & $2,385,000$ & $3,055,000$ & $3,955,000$ & $4,855,000$ \\
$\mathrm{PPh}: \mathrm{K} / 0$ & $1,683,750$ & $1,983,750$ & $2,283,750$ & $2,751,250$ & $3,651,250$ & $4,551,250$ \\
$\mathrm{PPh}: \mathrm{K} / 1$ & $1,582,500$ & $1,882,500$ & $2,182,500$ & $2,482,500$ & $3,347,500$ & $4,247,500$ \\
$\mathrm{PPh}: \mathrm{K} / 2$ & $1,481,250$ & $1,781,250$ & $2,081,250$ & $2,381,250$ & $3,043,750$ & $3,943,750$ \\
$\mathrm{PPh}: \mathrm{K} / 3$ & $1,380,000$ & $1,680,000$ & $1,980,000$ & $2,280,000$ & $2,740,000$ & $3,640,000$ \\
\hline
\end{tabular}

Berdasarkan tabel 1, pada omzet 300 juta rupiah diketahui bahwa jumlah PPh tertinggi sebesar $0.34 \%$ dari total omzet terjadi pada tingkat keuntungan 15\% dengan status TK/0. Sebaliknya, pada tingkat keuntungan 10\% dengan status K/2 dan K/3 PPh sebesar nol rupiah. Selanjutnya untuk tabel 2, 
pada omzet sebesar 400 juta rupiah, PPh tertinggi sebesar $0.44 \%$ dari total omzet terjadi pada tingkat keuntungan 15\% dengan status TK/0, dimana PPh terendah sebesar $0.09 \%$ dari omzet terjadi pada tingkat keuntungan 10\% dengan status K/3. Untuk tabel 3, pada omzet 500 juta rupiah, PPh tertinggi sebesar $0.52 \%$ pada tingkat keuntungan $15 \%$ dengan status TK/0 dan $\mathrm{PPh}$ terendah sebesar $0.17 \%$ pada tingkat laba 10\%dengan status K/3. Terakhir berdasarkan tabel 4, pada omzet 600 juta rupiah, PPh tertinggi sebesar $0.81 \%$ dari total omzet terjadi pada tingkat keuntungan sebesar $15 \%$ dengan status TK/0 dimana PPh terendah sebesar $0.23 \%$ pada tingkat keuntungan $10 \%$ dengan status K/3.

Sejak berlakunya PP nomor 46 tahun 2013 maka PPh atas usaha mikro dan menengah adalah sebesar $1 \%$ dari total omzet. Dengan demikian, PPh sebelum berlakunya PP nomor 46, lebih kecil dibandingkan $\mathrm{PPh}$ setelah berlakunya peraturan tersebut. Hal ini dapat diketahui dari PPh tertinggi sebelum berlakunya PP nomor 46 sebesar $0.81 \%$ dibandingkan setelah berlakunya PP 46 sebesar 1\% dari omzet.

\section{Implikasi Pajak Penghasilan usaha Mikro dan Menengah}

Pengenaan PPh berdasarkan PP nomor 46 telah menyederhanakan cara penghitungan PPh terhutang. Hal ini sejalan dengan arah kebijakan di berbagai negara berkembang seperti penyerderhanaan peraturan pajak, pengurangan compliance costs, taxpayer-friendly dengan penekanan pada usaha kecil dan WPOP (Arif and Pope, 2002). Penyederhanaan hukum pajak tidak selalu mencapai tujuan akhir penyederhanaan (James, Sawyer dan Wallschutzky, 1998) serta mencegah tax evasion. Oleh karena itu, sebagaimana argumentasi Kasipillai (2005) bahwa peraturan pajak seharusnya disederhanakan secara terus menerus untuk tiga alasan utama yaitu; mengurangi biaya administrasi dan compliance cost, ketidakpastian yang dihadapi oleh pembayar pajak dan meningkatkan tingkat voluntary compliance pembayar pajak.

Dengan pertimbangan untuk meningkatkan voluntary compliance pembayar pajak di masa mendatang maka review atas ketentuan perpajakan yang berlaku diperlukan secara terus menerus sebagaimana diargumentasikan oleh Kasipillai (2005). Oleh karena itu terkait PP 46, maka diperlukan kebijakan untuk menyinkronkan definisi usaha mikro dan kecil dari Kementrian UMKM dan Kementrian Keuangan. Sinkronisasi ini bertujuan untuk menyeragamkan batasan omzet yang digunakan dalam penghitungan pajak sehingga dapat memberikan rasa keadilan. Sebagai contoh, berikut diilustrasikan PPh WPOP usaha mikro yang memiliki omzet 300 juta rupiah dan WPOP usaha kecilyang memiliki usaha 2.5 milyar rupiah, dengan tingkat keuntungan $15 \%$ dan status $\mathrm{K} / 3$ berdasarkan UU PPh sebelum berlakunya PP nomor 46 tahun 2013, yang ditampilkan di tabel 5 berikut:

Tabel 5 PPh Pada Tingkat Keuntungan 15\%

\begin{tabular}{lrc}
\hline Omzet & $300,000,000$ & $2,500,000,000$ \\
Laba Bersih & $45,000,000$ & $375,000,000$ \\
PTKP K/3 & $32,400,000$ & $32,400,000$ \\
PhKP & $12,600,000$ & $342,600,000$ \\
PPh & 630,000 & $55,650,000$ \\
$\%$ PPh & 0.21 & 2.23 \\
\hline
\end{tabular}

Berdasarkan tabel 5, diketahui bahwa PPh WPOP dengan kategori usaha mikro, sebesar 0.21 \%, dibandingkan PPh usaha Kecil, sebesar $2.23 \%$. Ini berarti pengenaan PPh 1\% final berdasarkan PP nomor 46 tahun 2013 memberikan ketidakadilan bagi WPOP usaha mikro karena harus membayar $\mathrm{PPh}$ yang lebih besar sebesar $0.79 \%$,sebaliknya bagi usaha kecil mendapat keringanan pajak sebesar $1.23 \%$ dari total omzet. 
Mengingat usaha mikro sesuai UU Nomor 20 tahun 2008, adalah usaha dengan omzet di bawah 300 juta rupiah, maka bila diterapkan PPh tarif final 1\% dari omzet akan memberikan iklim yang tidak kodusif bagi usaha jenis ini yang kontribusinya sekitar $90.12 \%$ bagi penciptaaan lapangan kerja di Indonesia (Kementerian UMKM, 2012). Oleh karena itu, kebijakan pajak yang pro pada usaha mikro akanberimplikasi pada perekonomian nasional, mengingat perkembangan usaha secara umum dimulai dari usaha perorangan kecil yang bila berkembang menjadi usaha berbentuk badan dengan skala kecil hingga besar.

Untuk usaha menengah, dengan rentang peredaran usaha antara 600 juta rupiah hingga 2.5 miliar rupiah pengenaan pajak dengan tarif tunggal 1\% disamping memberi kemudahan dapat menimbulkan ketidakadilan bagi jenis usaha ini. Untuk memberikan gambaran, berikut perhitungan PPh WPOP usaha kecil, dengan omzet 600 juta rupiah dan 2.5 milyar rupiah pada tingkat keuntungan $15 \%$ dengan status K/3 sebagaimana di table 6 berikut:

Tabel 6 PPh Pada Tingkat Keuntungan 15\%

\begin{tabular}{lrr}
\hline Omz & $600,000,000$ & $2,500,000,000$ \\
NI & $90,000,000$ & $375,000,000$ \\
PTKP K/3 & $32,400,000$ & $32,400,000$ \\
PhKP & $57,600,000$ & $342,600,000$ \\
PPh & $3,640,000$ & $55,650,000$ \\
$\%$ PPh & 0.61 & 2.23 \\
\hline
\end{tabular}

Berdasarkan tabel 6, dapat diketahui bahwa dalam usaha kategori kecil, pada omzet 600 juta rupiah dengan status K/3 maka total PPh yang harus dibayar sebelum berlakunya PP 46 adalah sebesar $0.61 \%$, dibandingkan usaha kecil dengan omzet 2,5 milyar rupiah sebesar $2.23 \%$ dari omzet. Hal ini menunjukkan bahwa dalam usaha yang masuk kategori sama, penerapan PPh berdasarkan PP nomor 46 berimplikasi pada ketidakadilan bagi usaha dengan omzet 600 juta rupiah dibandingkan dengan omzet 2,5 milyar rupiah. Bagi WPOP usaha dengan omzet 600 juta rupiah membayar PPh lebih tinggi sebesar $0.39 \%$, sebaliknya WPOP dengan omzet 2.5 milyar membayar PPh dengan keringanan sebesar $1.23 \%$ dari omzet.

\section{SIMPULAN}

Paper ini menunjukkan bahwa, Peraturan Pemerintah nomor 46 tahun 2013 menyederhanakan penghitungan pajak penghasilan bagi WPOP UMKM karena untuk menghitung Pajak penghasilan terhutang tidak diperlukan penghitungan penghasilan kena pajak, namun hanya menghitung total penjualan sebulan untuk dikalikan tarif 1 persen dan bersifat final. Ini berarti, Peraturan Pemerintah nomor 46 tahun 2013 telah berhasil dalam mengurangi cost of taxation bagi WPOP usaha.

Untuk beban pajak penghasilan, paper ini membandingkan sebelum dan sesudah berlakunya Peraturan Pemerintah nomor 46 tahun 2013 pada usaha WPOP dengan omzet 300 juta rupiah untuk kategori usaha mikro,dan 400 juta rupiah, 500 juta rupiah, 600 juta rupiah untuk kategori usaha kecil. Dari pembahasan paper ini diketahui bahwa pada tingkat laba 10\%, WPOP usaha mikro status K/2 dan K/3 dengan omzet 300 juta rupiah, PPh terhutang adalah nihil. Sebaliknya, WPOP usaha mikro ini memiliki PPh terhutang sebesar 0.34 persen dari omzet pada tingkat laba $15 \%$ dengan status TK/0. Selanjutnya, PPh tertinggi sebesar $0.81 \%$ terjadi pada WPOP TK/0 dengan omzet 600 juta pada tingkat keuntungan 15 persen. 
Pengenaan PPh berdasarkan PP nomor 46 untuk kategori usaha mikro dan kecil dengan rentang omzet sampai dengan 2.5 milyar rupiah berimplikasi berbeda pada masing-masing jenis usaha maupun pada jenis usaha yang sama. PPh WPOP usaha mikro dengan omzet tertinggi sebesar 300 juta rupiah dengan status $\mathrm{K} / 3$, sebelum berlakunya $\mathrm{PP}$ nomor 46 , adalah sebesar $0.21 \%$ dari omzet. Sebaliknya pada jenis usaha kecil, PPh WPOP usaha pada omzet tertinggi sebesar 2.5 milyar rupiah adalah sebesar 2.23\% dari omzet dibandingkan PPh WPOP pada omzet 600 juta rupiah sebesar 0.61 persen.

Dengan demikian dapat disimpulkan untuk WPOP usaha Mikro dan kecil, dengan omzet sampai 600 juta rupiah, pengenanaan tarif PPh final 1\%berdasarkan PP nomor 46 tahun 2013 meningkatkan biaya PPh bagi WPOP jenis usaha ini dibandingkan sebelum berlakunya peraturan ini. Disamping itu, pengenaan PPh berdasarkan PP nomor 46 kurang memberikan rasa keadilan baik antara WPOP mikro dan kecil maupun antara WPOP usaha kecil. Untuk meminimalkan perbedaan beban PPh bagi WPOP usaha mikro dan menengah, maka pengenaan tarif yang lebih rendah bagi usaha mikro perlu dipertimbangkan disamping antar WPOP usaha kecil. Kombinasi antara tarif pajak rendah, prosedur sederhana, serta tindakan tegas untuk menegakkan kepatuhan kelihatan merupakan hal yang reasonable ke depan (OECD, 2012)

Mempertimbangkan keterbatasan paper ini yang lebih memfokuskan pembahasan pada WPOP usaha mikro dan kecil dengan omzet sampai 600 juta rupiah, maka pembahasan lengkap baik atas WPOP usaha maupun WP badan yang dikenakan PPh sesuai PP 46 diperlukan untuk memberikan gambaran yang menyeluruh atas PPh sesuai peraturan ini.

\section{DAFTAR PUSTAKA}

Ariff, M., Pope, J. (2002). Taxation \& Compliance Costs in Asia Pacific Economics. Sintok: University Utara Malaysia Press.

ESCAP (2012), Policy Guide Book for SME Development in Asia and the Pacific, United Nations Publication

Evans, C., Carlon, S., Massey, D. (2005). Record Keeping Practices and Tax Compliance of SMEs. eJournal of Tax Research, 3(2): 288-334

Freedman, J. (2003). "Small Business Taxation: Policy Issues and the UK." in Taxing Small Business: Developing Good Tax Policies. Australian Tax Research Foundation.

Hall, C. (2002). Profile of SMEs and SME issues in East Asia, in C. Harvie and B.C. Lee (eds.). The Role of Small and Medium Enterprises in National Economies in East Asia. Cheltenham, United Kingdom: Edward Elgar.

Inasius, F (2014), Kebijakan Angsuran Pajak Penghasilan Wajib Pajak Orang Pribadi Pengusaha Tertentu: Study Kasus Usaha Mikro di Indonesia, Binus Bussines Review.

IFC. (2007). Designing a Tax System for Micro and Smallbusiness. Guide for practitioners, Washington, D.C.: World Bank Group.

James, S., Sawyer, A., Wallschutzky, I. (1998), The Complexities of Tax Simplification: Progress in Australia, New Zealand and the United Kingdom. Australian Tax Forum. 
Kasipillai, J. (2005). A Comprehensive Guide to Malaysian Taxation: Current Year Assessment. Kuala Lumpur: McGraw-Hill.

OECD. (2012). Improving the Tax System in Indonesia. OECD Publishing.

Pope, J. (1993b). The Compliance Costs of Taxation in Australia and Tax Simplification: The Issues. Australian Journal of Management

Republik Indonesia. (2012). Kementerian Koperasi dan Usaha Kecil Menengah, Perkembangan data UMKM dan Usaha Besar tahun 2011-2012, diakses 22 Agustus 2014 dari http:// www.depkop.go.id

Republik Indonesia. (2000). Keputusan Direktur Jenderal Pajak Nomor 536/PJ./2000, Tentang Norma Penghitungan Penghasilan Neto Bagi Wajib Pajak yang dapat menghitung Penghasilan Neto dengan menggunakan Norma Penghitungan. Jakarta: Direktorat Jenderal Pajak Republik Indonesia.

Republik Indonesia. (2009). Peraturan Menteri Keuangan Nomor 208/PMK.03/2009 Tentang Penghitungan Besarnya Angsuran Pajak Penghasilan dalam Tahun Pajak Berjalan yang harus Dibayar Sendiri oleh Wajib Pajak Baru, Bank, Sewa Guna Usaha dengan Hak Opsi, Badan Usaha Milik Negara, Badan Usaha Milik Daerah, Wajib Pajak Masuk Bursa dan Wajib Pajak lainnya yang Berdasarkan Ketentuan diharuskan membuat Laporan Keuangan Berkala termasuk Wajib Pajak Orang Pribadi Pengusaha Tertentu. Jakarta: Kementerian Keuangan Republik Indonesia.

Republik Indonesia. (2012). Peraturan Menteri Keuangan Nomor 162/PMK.011/2012, Tentang Penyesuaian Besarnya Penghasilan Tidak Kena Pajak. Jakarta: Kementerian Keuangan Republik Indonesia.

Republik Indonesia. (2013). Peraturan Pemerintah Nomor 46 tahun 2013, Tentang Pajak Penghasilan Atas Penghasilan Dari Usaha Yang Diterima Atau Diperoleh Wajib Pajak Yang Memiliki Peredaran Bruto Tertentu. Jakarta: Lembar Negara Republik Indonesia Tahun 2013 Nomor 106. Kementerian Hukum dan HAM.

Republik Indonesia. (2008). Undang-Undang nomor 20 Tahun 2008 tentang Usaha Mikro Kecil dan Menengah. Lembaran Negara Republik Indonesia Tahun 2008 Nomor 93. Sekretariat Negara RI.

Republik Indonesia. (2008). Undang-Undang Nomor 36 Tahun 2008, tentang Pajak Penghasilan. Lembaran Negara Republik Indonesia Tahun 2008 Nomor 133. Sekretariat Negara RI.

Sandford, C., Godwin, M., Hardwick, P. (1989). Administrative and Compliance Costs of Taxation. Bath: U.K.: Fiscal Publication.

Sari, W. K. (2012). Tinjauan Kebijakan Norma Penghitungan Penghasilan Neto Berdasarkan Asas Kemudahan Administrasi dan Asas Keadilan, Tesis UI 